\title{
EFFECT OF SOYBEANS AND PALM OIL ADDITION TO THE COWS DIETS ON MILK FATTY ACID PROFILE
}

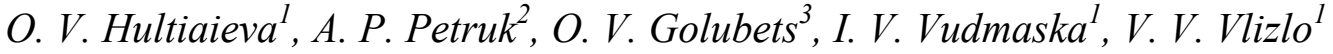 \\ inenbiol@mail.lviv.ua
}

${ }^{1}$ Institute of Animal Biology NAAS; 38 V. Stus St, Lviv, 79034, Ukraine

${ }^{2}$ Lviv National University of Veterinary Medicine and Biotechnologies named after S.Z. Gzhytsky; 50 Pekarska St, Lviv, 79010, Ukraine

${ }^{3}$ All-Ukrainian State Research and Production Center for Standardization, Metrology, Certification and Consumers' Rights Protection; 4 Metrologichna St, Kyiv, 03143, Ukraine

Effects of soybean and palm oil supplements on milk yields and fatty acids composition with considering intermediate products of unsaturated fatty acids hydrogenation were investigated. Fifteen multiparous Holstein cows in mid-lactation were assigned to groups of 5 each. Cows of control group fed ( $\mathrm{kg})$ : alfalfa hay - 6; corn silage - 20; grass silage - 10; wheat - 3; corn - 2; soybean meal - 1; molasses - 2. In the diet of the 1st treated group, soybean meal was replaced by $1.5 \mathrm{~kg}$ of extruded soybeans. Diet of 2 nd treated group cows was supplemented with $0.3 \mathrm{~kg}$ of palm oil. All diets were equivalent in contents of nutrients (except fat). Crude fat content in the diets was 0.70, 0.96 and $0.97 \mathrm{~kg} / \mathrm{cow} /$ day, respectively. Treatment lasted 2 months. Milk yield was recorded weekly for the duration of the study. The milk fatty acids methyl esters were then quantified by gas chromatography.

In the milk of cows fed diet with soybeans was found 2.2 times more of trans-11 18:1 $(P<0.001)$ and 1.3 times more of cis-9,trans11 18:2 $(P<0.05)$ fatty acids compared to cows of control group. Trans-11 18:1 and cis-9,trans11 18:2 act in animal and human tissues as antagonists of $\omega-6$ fatty acids and, respectively, they are synergists of $\omega-3$ fatty acids. Thus an increased content of these acids improves milk dietary value.

Cows of both treated groups had higher milk protein yield for $40 \mathrm{~g}$ daily $(P<0.05)$. Milk fat yield was increased only in cows fed palm oil, it was 50 g greater than in control cows $(P<0.05)$. Both fat supplements increased the average daily milk yields. Milk yield of cows fed diet with soybeans addition was higher by $4 \%(P<0.05)$, and in cows fed diet with palm oil milk yield grew to $7 \%(P<0.05)$. Fat corrected milk yield was increased only in cows fed diet with palm oil addition $(P<0.05)$. The results of the present study indicate a benefits of feeding cows by palm oil as dietary supplement.

Keywords: COWS, MILK, FATTY ACIDS, SOYBEANS, PALM OIL

\section{ЖИРНОКИСЛОТНИЙ СКЛАД ЛІПІДІВ МОЛОКА ЗА ДОДАВАННЯ ДО РАЦІОНУ КОРІВ СОЕВИХ БОБІВ ТА ПАЛЬМОВОЇ ОЛІЇ}

\author{
О. В. Гультяєва ${ }^{1}$, А. П. Петрук ${ }^{2}$, О. В. Голубецьь ${ }^{3}$, I. В. Вудмаска ${ }^{1}$, В. В. Влізло \\ inenbiol@mail.lviv.ua
}

\footnotetext{
${ }^{1}$ Інститут біології тварин НААН, вул. В. Стуса, 38; м. Львів, 79034, Україна

2 Львівський національний університет ветеринарної медицини та біотехнологій імені С. 3. Гжицького, вул. Пекарська, 50; м. Львів, 79010, Україна

${ }^{3}$ Всеукраїнський державний науково-виробничий центр стандартизації, метрології, сертифікації і захисту прав споживачів (Укрметртестстандарт), вул. Метрологічна 4, м. Київ, 03143, Україна
} 
Додавання до ращуіону високопродуктивних корів жирових добавок позитивно впливає на обмін речовин, підвищує молочну продуктивність та якість молока. Це пояснюється високою енергетичною иінністю жирів, їх нітрогензберігаючою дією $в$ організмі корів, використання наявних у жирі жирних кислот у синтезі ліпідів молока.

Дослідження було проведено на 3 групах корів-аналогів украӥнської чорно-рябої молочної породи, по п'ять голів у кожній, продуктивністю 20-25 кг молока за добу. Корови контрольної групи отримували стандартний збалансований за вмістом поживних речовин раціон, щуо містив 670 г сирого жиру. Вміст жиру у рачіонах корів 2-i та 3-ї груп збільшували на $50 \%$ за рахунок введення до їх складу відповідно соєвих бобів або пальмової олії. Рачіон контрольних корів складався з (кг): сіна лючернового - 6,0, силосу кукурудзяного - 20, сінажу - 10, дерті пшеничної - 3,0, дерті кукурудзяної 2,0, шроту соєвого - 1,0, меляси - 2,0. У раміоні корів 1-ї дослідної групи соєвий шрот замінювали на 1,5 кг соєвих бобів, а до раціону корів 2-ї дослідної групи додавали 0,3 кг пальмової олії. Тривалість досліду становила 2 місяиі. У кіниі досліду відбирали вмістиме рубия, кров $i$ молоко. Жирнокислотний склад ліпідів плазми крові досліджували методом газорідинної хроматографіï на хроматографі Hewlett Packard HР-6890 з полум'яно-іонізачійним детектором, обладнаному капілярною колонкою SP-2560 довжиною 100 м.
Зміна ліпідного та жирнокислотного складу рачіону вплинула на жирнокислотний склад молочного жиру. У молочі корів 1-ї дослідної групи зменшилась кількість кислот ізо-15:0, антеізо-15:0 і 17:0 $(P<0,05-0,01) \mathrm{ma}$ зростала кількість 18:1 та 18:2 кислот $(P<0,01-0,001)$. У молочі корів 2-ї дослідної групи зросла кількість 14:0 кислоти $(P<0,05)$. У складі молочного жиру корів 1-ї дослідної групи виявлено у 2,2 рази більше кислоти транс-11 18:1 $(P<0,001)$ та у 1,3 рази більше ї̈ метаболіту - кислоти иис-9,транс-11 18:2 $(P<0,05)$. У корів 2-ї дослідної групи вміст транс-11 18:1 $(P<0,05)$ - був вищим у 1,3 рази, а вміст иисс-9,транс-11 18:2 - у 1,2 рази. Частка лінолевої (иис-9,12 18:2) кислоти у молоиі корів 1-ї дослідної групи зростала $(P<0,001), \quad$ а $2-\ddot{i} \quad$ дослідної групи зменшувалась $(P<0,01) . \quad$ У молочній залозі зменшувався синтез коротколанцюгових жирних кислот: С4:0, С6:0 і С8:0 (P<0,05$0,01)$.

Вміст жиру у молочі корів контрольної та 1-ї $і$ i $2-\ddot{i}$ дослідних груп становив, відповідно, 3,54; 3,37 i 3,51\%. Обидві жирові добавки підвищували середньодобові надої корів: у 1-й дослідній гpyni на $4 \%(P<0,05)$, а у у $2-\check{u}-$ на $7 \%$ $(P<0,05)$, проте у перерахунку на базисну жирність надої зростали лиме у корів 2-ї дослідної групи $(P<0,05)$.

\begin{tabular}{llr}
\multicolumn{2}{c}{ Ключові слова: } & КОРОВИ, \\
МОЛОКО, & ЖИРН КИСЛОТИ, & СОЕВІ \\
БОБИ, & ПАЛЬМОВА & ОЛІЯ
\end{tabular}

\title{
ЖИРНОКИСЛОТНЫЙ СОСТАВ ЛИПИДОВ МОЛОКА ПРИ ДОБАВЛЕНИИ К РАЦИОНУ КОРОВ СОЕВЫХ БОБОВ И ПАЛЬМОВОГО МАСЛА
}

\author{
А. В. Гультяева ${ }^{1}$, А. П. Петрук ${ }^{2}$ О. В. Голубеиь ${ }^{3}$, И. В. Вудмаска ${ }^{1}$ В. В. Влизло \\ inenbiol@mail.lviv.ua
}
${ }^{1}$ Институт биологии животных НААН, ул. В. Стуса, 38; г. Львов, 79034, Украина
${ }^{2}$ Львовский национальный университет ветеринарной медицины и биотехнологий имени С. 3. Гжицкого, ул. Пекарська, 50; г. Львов, 79010, Украина
${ }^{3}$ Всеукраинский государственный научно-производственный центр стандартизации, метрологии, сертификации и защиты прав потребителей (Укрметртестстандарт), ул. Метрологическая, 4, г. Киев, 03143, Украина

Добавление высокопродуктивных коров жировых добавок положительно влияет на обмен веществ, повышает молочную продуктивность и качество молока. Это объясняется высокой энергетической ценностью жсиров, их азотсохраняюшим действием в организме 
коров, использование имеющихся в жире жирных кислот для синтеза липидов молока.

Исследование было проведено на 3-x группах коров-аналогов украинской чернопестрой молочной nороды, по пять голов в группе, производительностью 20-25 кг молока в сутки. Коровы контрольной группь получали стандартный сбалансированный по содержанию питательных вещчеств рацион, содержавший $670 \quad 2$ сырого жира. Содержание жира в рацчионах коров 2-й и 3-й групп увеличивали на $50 \%$ за счет введения в их состав в соответствии соевьх бобов или пальмового масла. Рацион контрольных коров состоял из (кг): сена лючернового - 6, силоса кукурузного - 20, сенажа - 10, дерти пшеничной - 3, дерти кукурузной - 2, шрота соевого - 1, мелассы - 2. В рационе коров 1-й опьттной группы соевылй шрот заменяли 1,5 к2 соевых бобов, а к рациону коров 2-й опьтной группь добавляли 0,3 г пальмового масла. Продолжительность опьта 2 месяияа. Жирнокислотный состав липидов плазмы молока исследовали методом газожидкостной хроматографии на хроматографе Hewlett Packard HР-6890 с пламенно-ионизационным детектором, оборудованным капиллярной колонкой SP-2560 длиной 100 м.

$$
\text { Изменение }
$$$$
\text { липидного }
$$

жирнокислотного состава рациона повлияло на жирнокислотный состав молочного жира. $B$ молоке коров 1-й опьтной группь уменьиилось содержание кислот изо-15:0, антеизо-15:0 и 17:0 (P<0,05-0,01) и больше 18:1 и 18:2 кислот $(P<0,01-0,001)$. В молоке коров 2-й опьтной группьг возросло количество 14:0 кислоты $(P<0,05)$. В составе молочного жира коров 1-й опьтной группь обнаружено в 2,2 раза больше кислоты транс11 18:1 $(P<0,001)$ и в 1,3 раза больше ее метаболита - кислоты иис-9,транс-11 18:2 $(P<0,05) . \quad$ У коров 2-й опьтной группь содержание транс-11 $18: 1 \quad(P<0,05)$ было выме в 1,3 раза, а содержание иис-9,транс-11 18:2 - в 1,2 раза. Количество линолевой (цис9,12 18:2) кислоты в молоке коров 1-й опьттной группь увеличилось $(P<0,001)$, а 2-й опьттной группь - уменьшилось $(P<0,01)$. В молочной железе снизился синтез короткоцуепочечных жирных кислот: 4:0, 6:0 и 8:0 $(P<0,05-0,01)$.

Содержание жира в молоке коров контрольной, $1-\check{u}$ u $2-\check{u}$ опьттных групп составил, соответственно, 3,54; 3,37 u 3,51\%. Обе жировые добавки повышали среднесуточные удои коров. В 1-й опытной zpynnе на $4 \%(P<0,05)$, а во $2-\check{u}-$ на $7 \%$
$(P<0,05)$, однако в пересчете на базисную жирность надои возросли только у коров 2-й опьтнной группь $(P<0,05)$.

\section{Ключевые слова: КОРОВЫ, МОЛОКО, ЖИРНЫЕ КИСЛОТЫ, СОЕВЫЕ БОБЫ, ПАЛЬМОВОЕ МАСЛО}

Dietary sources of lipids can be added to the diet of lactating dairy cows to increase the energy density of the diet, modify milk production, and milk fatty acids profile [1-5]. Cows receiving fat supplements produce more milk per unit of consumed dry matter, due to better energy use associated with lower energy losses in the rumen, more efficient production of ATP from long-chain fatty acids than from acetate, direct inclusion of long-chain fatty acids in the fat milk [6]. Fat supplements to the cows diet decrease energy loss on thermoregulation and methanogenesis, reduce the risk of ruminal acidosis. Moreover, fat supplementation has some other effects, such as increased absorption of fat-soluble nutrients and reduced dustiness of feed [5].

Fat digestion and metabolism in ruminants has several features associated with fermentation in the rumen. Double bounds of dietary unsaturated fatty acids are isomerizes and saturated by ruminal bacteria [1-3]. In addition, ruminal bacteria synthesize specific fatty acids with odd and branched carbon chains [7]. Triglycerides of the diet are largely hydrolyzed by microbial lipases of rumen to yield free fatty acids, and double bounds of unsaturated fatty acids in turn undergo biohydrogenation to stearic acid and positional and geometrical isomers of oleic, linoleic and linolenic acids that delivered to the small intestine, absorbed to the blood and used by the organism, including for the synthesis of milk fat [1-3]. As a result, unsaturated fatty acids, including $\alpha$-linolenic acid (cis-9,12,15 18:3) and linoleic acid (cis9,12 18:2), are abundant in grass and certain other ruminant feedstuffs, yet are present at low concentrations in ruminant meat and milk.

Such intermediates of biohydrogenation as conjugated linoleic acid probably possess important metabolic properties. Cis-9,trans-11 18:2 is generally considered to be the main health-promoting 
conjugated linoleic acid for human consumption [8,9]. The trans-11 18:1 fatty acid, an intermediate of biohydrogenation, is also desirable as a product flowing from the rumen because trans-11 18:1 acts as a substrate for the formation of cis-9, trans$1118: 2$ in the animal's own tissues [10]. Dietary cis-9,trans-11 conjugated linoleic acid have been shown in many animal studies to contribute to cancer prevention, decreased atherosclerosis, improved immune response, and altered protein or energy metabolism. Trans-10,cis-12 18:2 isomer reduces body fat $[8,11,12]$. Therefore, ruminant products contain potentially health-promoting conjugated linoleic acids mainly cis-9,trans11 18:2 and trans-10,cis-12 18:2.

The main aim of investigations into ruminal biohydrogenation is to create healthier ruminant products. Increased milk concentration of both conjugated linoleic acid can be obtained by feeding of oilseeds and other fat supplements [14-17]. The objective of this experiment was to compare the effects of soybeans and palm oil feed supplement on cows' milk production and composition. Conjugated linoleic acid has drawn significant attention in the last two decades for its variety of biologically beneficial effects. At the same time, some researchers are skeptical of positive actions based on traditional ideas about the impact of trans fatty acids, so further research is needed to determine the health effects of trans-11 18:1 and cis9,trans-11 18:2 acids [18, 19].

\section{Materials and methods}

Fifteen multiparous Holstein cows in midlactation were assigned to five treatments. The study was preceded by a 3 weeks randomized covariate period. All cows were fed the same diet during the covariate period and had free access to water. Diets were fed twice daily in equal. Cow's diets consisted of (kg): alfalfa hay - 6; corn silage - 20; grass silage -10 ; wheat -3 ; corn - 2 ; soybean meal - 1; molasses - 2. After that cows were assigned to groups of 5 each. Cows of control group further fed the same diet. In the diet of 1st experimental group soybean meal was replaced by $1.5 \mathrm{~kg}$ of extruded at $130{ }^{\circ} \mathrm{C}$ exit temperature soybeans. Diet of $2 \mathrm{nd}$ experimental group cows was supplemented with $0.3 \mathrm{~kg}$ of palm oil. All diets were equivalent in contents of nutrients (except fat): crude protein -3.2 , crude fiber -4.5 , starch - 2.9, sugar - 1.7. Crude fat content in these diets was 0.70, 0.96, $0.97 \mathrm{~kg} / \mathrm{cow} /$ day, respectively. Experimental period lasted 2 months.

Milk yield was recorded weekly for the duration of the study. Samples collected for the determination of protein, fat, and lactose were taken from two consecutive milkings of each week. Milk samples for the determination of fatty acid profiles were collected during the last week of test periods. Milk fat, protein, and lactose were determined by milk analyzer Ecomilk (Bulgaria).

Fatty acids methyl esters were prepared by ISO 15884:2002 [20]. Milk fatty acids were measured as described in ISO 15885:2002 [21]. Fatty acids were expressed as percentage of total fatty acids. The fatty acids methyl esters were then quantified by gas chromatograph Hewlett Packard HP-6890 with capillary column HP-88 (Agilent Technologies) $100 \mathrm{~m}$ lengths, $0.25 \mathrm{~mm}$ diameter, stationary phase film thickness 0.2 $\mathrm{mcm}$. The temperature settings were $280{ }^{\circ} \mathrm{C}$ for the injector and $290{ }^{\circ} \mathrm{C}$ for the detector, and the column oven was temperature programmed from 40 to $260{ }^{\circ} \mathrm{C}$. Flow rate for the carrier gas $(\mathrm{He})$ was $1.2 \mathrm{ml} / \mathrm{min}$. Peaks were quantified by peak area comparisons with a known amount of an internal standard (heptadecanoic acid, Sigma). Peaks were identified by comparison with known commercially prepared standards (37 component FAME mix, Supelco, № 47885-U; CLA isomers mix, Sigma-Aldrich, № 05632).

The SEM were calculated in Excel by dividing the SD by the square root of sample size. Statistics between control and each of experimental groups were calculated by ttest function in the Excel. Differences were considered significant at $\mathrm{P}<0.05$.

\section{Results and discussion}

Changes in fatty acid composition of cows diet affected the fatty acid profile of milk fat (tabl. 1). Increasing of dietary fat content decreased the synthesis of some short- 
chain fatty acids (particularly: butyric (4:0), caproic $(6: 0)$ and caprylic $(8: 0) \quad(\mathrm{P}<0.05-$ $0.01)$ ) by mammary gland of cows both treated groups. Additionally, milk of cows fed soybeans contained less myristic (14:0) acid $(\mathrm{P}<0.01)$, which is caused by more intensive usage of dietary fatty acids for milk synthesis in cows received fat supplements. Increased level of typical for palm oil myristic (14:0) acid $(\mathrm{P}<0.05)$ was found in a large amount in the milk of 2 nd experimental group cows.

Fatty acid profile of cows milk (\% of total fatty acids), $\Sigma \pm \operatorname{SEM}(n=5)$

\begin{tabular}{|c|c|c|c|}
\hline \multirow[b]{2}{*}{ Fatty acids } & \multicolumn{3}{|c|}{ Cows groups } \\
\hline & Control & $\begin{array}{l}\text { 1st experimental } \\
\text { (soybeans) }\end{array}$ & $\begin{array}{l}\text { 2nd experimental } \\
\quad \text { (palm oil) }\end{array}$ \\
\hline C 4:0 & $3.12 \pm 0.06$ & $2.95 \pm 0.08$ & $2.74 \pm 0.13 *$ \\
\hline C 6:0 & $1.44 \pm 0.04$ & $1.21 \pm 0.09 *$ & $1.29 \pm 0.04^{*}$ \\
\hline C 8:0 & $1.95 \pm 0.06$ & $1.56 \pm 0.06^{* *}$ & $1.52 \pm 0.07 *$ \\
\hline C 10:0 & $5.23 \pm 0.26$ & $5.29 \pm 0.34$ & $5.44 \pm 0.24$ \\
\hline C 12:0 & $5.4 \pm 10.08$ & $4.59 \pm 0.20 * *$ & $5.93 \pm 0.30$ \\
\hline C 14:0 & $11.75 \pm 0.78$ & $10.88 \pm 0.43$ & $13.99 \pm 0.46^{*}$ \\
\hline Iso-C15:0 & $0.34 \pm 0.01$ & $0.18 \pm 0.02 *$ & $0.21 \pm 0.02 *$ \\
\hline Anteiso-C15:0 & $0.33 \pm 0.03$ & $0.21 \pm 0.02 * *$ & $0.35 \pm 0.03$ \\
\hline C 14:1 & $0.86 \pm 0.04$ & $1.11 \pm 0.04 * *$ & $1.05 \pm 0.04 * *$ \\
\hline C 15:0 & $1.08 \pm 0.09$ & $0.96 \pm 0.04$ & $0.92 \pm 0.06$ \\
\hline C 16:0 & $26.83 \pm 1.26$ & $23.24 \pm 1.02$ & $25.66 \pm 0.44$ \\
\hline Iso-C17:0 & $0.30 \pm 0.03$ & $0.28 \pm 0.04$ & $0.37 \pm 0.03$ \\
\hline C 16:1 & $1.72 \pm 0.06$ & $1.64 \pm 0.08$ & $1.73 \pm 0.06$ \\
\hline Anteiso-C17:0 & $0.25 \pm 0.02$ & $0.21 \pm 0.02$ & $0.26 \pm 0.02$ \\
\hline C 17:0 & $0.55 \pm 0.06$ & $0.39 \pm 0.04 * *$ & $0.52 \pm 0.09$ \\
\hline C 17:1 & $0.15 \pm 0.02$ & $0.20 \pm 0.01$ & $0.18 \pm 0.01$ \\
\hline C 18:0 & $11.18 \pm 0.53$ & $11.88 \pm 0.65$ & $10.57 \pm 0.47$ \\
\hline C $18: 16 \mathrm{t}$ & $0.20 \pm 0.01$ & $0.24 \pm 0.02$ & $0.22 \pm 0.01$ \\
\hline C $18: 19 t$ & $0.14 \pm 0.01$ & $0.17 \pm 0.02$ & $0.19 \pm 0.03 * *$ \\
\hline C 18:1 10t & $0.48 \pm 0.03$ & $0.53 \pm 0.04$ & $0.47 \pm 0.02$ \\
\hline C 18:1n 11t & $0.82 \pm 0.03$ & $1.84 \pm 0.04 * * *$ & $1.09 \pm 0.05^{*}$ \\
\hline C 18:1 6c & $0.35 \pm 0.03$ & $0.33 \pm 0.05$ & $0.25 \pm 0.03 *$ \\
\hline C 18:1 9c & $18.03 \pm 1.11$ & $21.10 \pm 0.41 *$ & $18.19 \pm 1.06$ \\
\hline C $18: 111 \mathrm{c}$ & $0.38 \pm 0.03$ & $0.45 \pm 0.04$ & $0.36 \pm 0.04$ \\
\hline C 18:1 12c & $0.31 \pm 0.03$ & $0.35 \pm 0.03$ & $0.42 \pm 0.02 *$ \\
\hline C 18:2 10t,12c & $0.15 \pm 0.02$ & $0.13 \pm 0.01$ & $0.12 \pm 0.01$ \\
\hline C 18:2 9c,12c & $2.81 \pm 0.06$ & $3.97 \pm 0.05 * * *$ & $2.21 \pm 0.06^{* *}$ \\
\hline C 18:2 9c,11t & $1.04 \pm 0.07$ & $1.30 \pm 0.12 *$ & $1.21 \pm 0.08$ \\
\hline C 19:0 & $0.10 \pm 0.01$ & $0.08 \pm 0.01$ & $0.09 \pm 0.01$ \\
\hline C 20:0 & $0.11 \pm 0.01$ & $0.10 \pm 0.01$ & $0.12 \pm 0.01$ \\
\hline C $18: 3 n 3$ & $1.66 \pm 0.06$ & $1.72 \pm 0.14$ & $1.45 \pm 0.07 *$ \\
\hline C 20:1n9 & $0.13 \pm 0.02$ & $0.13 \pm 0.03$ & $0.10 \pm 0.01$ \\
\hline C 22:0 & $0.15 \pm 0.03$ & $0.17 \pm 0.02$ & $0.14 \pm 0.02$ \\
\hline C 20:3n9 & $0.14 \pm 0.02$ & $0.16 \pm 0.02$ & $0.18 \pm 0.03$ \\
\hline C 20:4n6 & $0.50 \pm 0.01$ & $0.43 \pm 0.06$ & $0.45 \pm 0.04$ \\
\hline Odd-chain & $3.11 \pm 0.05$ & $2.50 \pm 0.08 * * *$ & $2.90 \pm 0.08 *$ \\
\hline Branched-chain & $1.23 \pm 0.03$ & $0.88 \pm 0.06^{* * *}$ & $1.19 \pm 0.03$ \\
\hline Saturated & $70.14 \pm 1.06$ & $64.19 \pm 0.51 * *$ & $70.13 \pm 1.08$ \\
\hline Polyunsaturated & $6.30 \pm 0.08$ & $7.71 \pm 0.24 * *$ & $5.62 \pm 0.17 * *$ \\
\hline Total trans 18:1 & $1.63 \pm 0.07$ & $2.79 \pm 0.07 * *$ & $1.98 \pm 0.04 * *$ \\
\hline Total of cis 18:1 & $19.07 \pm 1.10$ & $22.24 \pm 0.41$ & $19.23 \pm 1.09$ \\
\hline Total of cis 18:1 without 9cis & $1.05 \pm 0.02$ & $1.14 \pm 0.08$ & $1.04 \pm 0.06$ \\
\hline $20: 3 n 9 / 20: 4 n 6$ & $0.28 \pm 0.04$ & $0.42 \pm 0.10$ & $0.42 \pm 0.09$ \\
\hline 18:2 9c,11t/trans-11 18:1 & $1.28 \pm 0.08$ & $0.70 \pm 0.05 * *$ & $1.12 \pm 0.07$ \\
\hline
\end{tabular}

Note: Statistical probabilities of treatment differences compared to the control group: $*-P<0.05$; $* *-P<0.01 ; * * *-P<0.001$ 
Content of other dominant acid palmitic (16:0) was about the same in the milk of all groups what can be explained by an efficient synthesis of palmitic acid by mammary gland of cows and therefore less influence of diet on this fatty acid presence in the milk.

Milk from cows of 1st experimental group had fewer iso-15:0, anteiso-15:0 and margaric (17:0) acids $(\mathrm{P}<0.05-0.01)$, which are synthesized by ruminal bacteria and enter the blood through the digestive tract. Milk of 1 st experimental group cows has higher quantity of 18:1 and 18:2 acids because these fatty acids dominate in soybean lipids $(\mathrm{P}<0.01-0.001)$.

Supplementation of cows diet by fat with different fatty acids profile differently influenced the unsaturated fatty acids hydrogenation in the rumen and therefore on the ratio of unsaturated fatty acids isomers in milk.

Milk fat of cows of 1 st experimental group contains 2.2 times more trans-11 18:1 $(\mathrm{P}<0.001)$ and 1.3 times more its metabolite - cis-9, trans-11 18:2 $(\mathrm{P}<0.05)$ compared to the milk fat of control group cows.

These acids performing the function of $\omega-6$ fatty acids antagonists and are synergists of $\omega-3$ fatty acids in animals and human tissues, so increased level of trans-11 18:1 and cis-9,trans-11 18:2 improves biological value of milk fat.

The level of these 18:1 and 18:2 isomers in the milk of cows of the 2 nd experimental group increased also but a much lesser degree. The contents of trans-11 18:1 and cis-9,trans-11 18:2were 1.3 and 1.2 times higher than in control group but changes were statistically significant only for trans-11 18:1
$(\mathrm{P}<0.05)$. Another important change in the fatty acid composition of unsaturated fatty acids is a significantly increased content of linoleic (cis-9,12 18:2) acids in the milk of 1st experimental group cows $(\mathrm{P}<0.001)$ and decrease its level in the milk of 2 nd experimental group cows $(\mathrm{P}<0.01)$. Apparently, it's due to different contents of this acid in soybean and palm oils.

The other significant change in milk fat composition was reduced total amounts of branch- and odd-chain fatty acids in cows fed soybeans $(\mathrm{P}<0.001)$. These acids are typical for bacteria of rumen, thus reduced its quantity indicates the suppression of ruminal microflora by polyunsaturated fatty acids of soybeans. Another reason for these effects is a reduced synthesis of fatty acids by bacteria when a large amount of dietary fat is receiving; in this case the bacteria partially used exogenous fatty acids. By this we may also explain the slightly decreased odd-chain fatty acids in milk of cows fed palm oil $(\mathrm{P}<0.05)$.

Milk fat of cows fed soybeans contains more polyunsaturated $(\mathrm{P}<0.01)$ and less saturated $(\mathrm{P}<0.01)$ fatty acids than milk fat of control cows. However, content of polyunsaturated acids in the milk fat of cows fed palm oil was lower than in controls group $(\mathrm{P}<0.01)$. This is due to differences in the fatty acid composition of the investigated fat supplements.

Both fat supplements increased the average daily milk yields (Table 2 ), in the 1 st experimental group by $4 \%(\mathrm{P}<0.05)$ and in the 2 nd experimental group by $7 \%(\mathrm{P}<0.05)$, but fat corrected milk yields were higher only in cows fed palm oil $(\mathrm{P}<0.05)$.

Milk production, $\Sigma \pm \operatorname{SEM}(\mathbf{n}=\mathbf{5})$

\begin{tabular}{|l|c|c|c|}
\hline \multirow{2}{*}{\multicolumn{1}{c|}{ Parameters }} & \multicolumn{2}{c|}{ Cows groups } \\
\cline { 2 - 4 } & Control & $\begin{array}{c}\text { 1st experimental } \\
\text { (soybeans) }\end{array}$ & $\begin{array}{c}\text { 2nd experimental } \\
\text { (palm oil) }\end{array}$ \\
\hline Daily milk yield, kg & $24.40 \pm 0.77$ & $25.48 \pm 0.83^{*}$ & $26.04 \pm 0.61^{*}$ \\
\hline Fat corrected milk yield (3.4\%), kg & $25.31 \pm 0.64$ & $25.25 \pm 1.10$ & $26.84 \pm 0.39^{*}$ \\
\hline Milk protein, \% & $3.30 \pm 0.05$ & $3.33 \pm 0.05$ & $3.28 \pm 0.03$ \\
\hline milk fat, \% & $3.54 \pm 0.12$ & $3.37 \pm 0.09^{*}$ & $3.51 \pm 0.07$ \\
\hline Lactose, \% & $4.35 \pm 0.12$ & $4.36 \pm 0.08$ & $4.37 \pm 0.14$ \\
\hline Daily protein yield, kg & $0.81 \pm 0.03$ & $0.85 \pm 0.04^{*}$ & $0.85 \pm 0.01^{*}$ \\
\hline Daily fat yield, kg & $0.86 \pm 0.02$ & $0.86 \pm 0.04$ & $0.91 \pm 0.02^{*}$ \\
\hline Daily lactose yield, kg & $1.06 \pm 0.05$ & $1.11 \pm 0.02$ & $1.14 \pm 0.04$ \\
\hline
\end{tabular}




\section{Conclusions}

Replacement of dietary soybean meal by full-fat soybeans or palm oil addition to the diet modifies cow's milk fatty acid composition. Polyunsaturated lipids of soybeans enhanced the content of healthy beneficial trans-11 isomers of octadecenic and octadecadienoic fatty acids in the milk fat. However, soybeans have reduced the milk fat synthesis. Palm oil is low in polyunsaturated fatty acids, so it is less affected the formation of trans- isomers of fatty acids and didn't inhibit the synthesis of milk fat. Both fat supplements increased milk yield of cows, but fat corrected milk yield has increased only by palm oil addition. Obtained results points out the effectiveness of the use of palm oil as a fat supplement for the diet of lactating cows.

1. Bauman D. E., Mather I. H., Wall R. J., Lock A. L. Major advances associated with the biosynthesis of milk. J. Dairy Sci., 2006, vol. 89, pp. 1235-1243.

2. Eastridge M. L. Major advances in applied dairy cattle nutrition. J. Dairy Sci., 2006, vol. 89 , pp. 1311-1323.

3. Jenkins T. C., McGuire M. A. Major advances in nutrition: impact on milk composition. J. Dairy Sci., 2006, vol. 89, pp. 1302-1310.

4. Vudmaska I. V. Zhyry u hodivli vysokoproduktyvnykh koriv [Fats in cows nutrition]. Tvarynnytstvo Ukrainy - Livestock of Ukraine, 2006, №9, pp.24-27 (in Ukrainian).

5. Nutrient Requirements of Dairy Cattle. National Research Council, Seventh revised edition, National Academy Press, Washington, DC, 2001, 408 p.

6. Russell J. B., Wallace R. J. Energy yielding and consuming reactions. In: The Rumen Microbial Ecosystem [ed. P. N. Hobson], NY. Elsevier Sci. Publ., 1988, pp. 185-216.

7. Bas P., Archimede H., Rouzeau A., Sauvant D. Fatty acid composition of mixedrumen bacteria: Effect of concentration and type of forage. J. Dairy Sci., 2003, vol. 86, pp. 29402948.

8. Churruca I., Fernández-Quintela A., Portillo M. P. Conjugated linoleic acid isomers: differences in metabolism and biological effects. Biofactors, 2009, vol. 35(1), pp. 105-111.

9. Dilzer A, Park Y. Implication of conjugated linoleic acid (CLA) in human health. Crit. Rev. Food Sci. Nutr., 2012, no. 52 (6), pp.488-513.
10. Palmquist D. L., Lock A. L., Shingfield K. J., Bauman D. E. Biosynthesis of conjugated linoleic acid in ruminants and humans. Adv. Food Nutr. Res., 2005, vol. 50, pp. 179-217.

11. Chouinard P. Y., Corneau L., Barbano D. M., Metzger L. E., Bauman D. E. Conjugated linoleic acids alter milk fatty acid composition and inhibit milk fat secretion in dairy cows. $J$. Nutr., 1999, vol. 129, pp. 1579-1584.

12. Kennedy A., Martinez K., Schmidt S., Mandrup S., LaPoint K., McIntosh M. Antiobesity mechanisms of action of conjugated linoleic acid. J. Nutr. Biochem., 2010, vol. 21 (3), pp. 171-179.

13. An J. K., Kang C. W., Izumi Y., Kobayashi Y., Tanaka K. Effects of dietary fat sources on occurrences of conjugated linoleic acid and trans fatty acids in rumen contents. AJAS, 2003, vol. 16, pp. 222-226.

14. Bell J. A., Griinari J. M., Kennelly J. J. Effect of safflower oil, flaxseed oil, monensin, and vitamin $\mathrm{E}$ on concentration of conjugated linoleic acid in bovine milk fat. J. Dairy Sci., 2006, vol. 89, no. 2, pp. 733-748.

15. Rego O. A, Alves S. P, Antunes L. M., Rosa H. J, Alfaia C. F, Prates J. A, Cabrita A. R., Fonseca A. J., Bessa R. J. Rumen biohydrogenation-derived fatty acids in milk fat from grazing dairy cows supplemented with rapeseed, sunflower, or linseed oils. J. Dairy Sci., 2009, vol. 92(9), pp. 4530-4540.

16. Offer N. W., Marsden M., Phipps R. H. Effect of oil supplementation of a diet containing a high concentration of starch on levels of trans- fatty acids and conjugated linoleic acids in bovine milk. Anim. Sci., 2001, vol. 73, pp. 533540.

17. Zheng H. C., Liu J. X., Yao J. H., Yuan Q., Ye H. W., Ye J. A., Wu Y. M. Effects of dietary sources of vegetable oils on performance of high-yielding lactating cows and conjugated linoleic acids in milk. J Dairy Sci., 2005, vol. 88(6), 2037-2042.

18. Gebauer S. K., Chardigny J.-M., Jakobsen M. U., Lamarche B., Lock A. L., Proctor S. D., Baer D. J. Effects of ruminant trans fatty acids on cardiovascular disease and cancer: A comprehensive review of epidemiological, clinical, and mechanistic studies. Adv. Nutr., 2011, vol. 2, pp. 332-354.

19. McCrorie T. A., Keaveney E. M., Wallace J. M., Binns N., Livingstone M. B. Human health effects of conjugated linoleic acid from milk and supplements. Nutr. Res. Rev., 2011, vol. 24(2), pp.206-227.

20. ISO 15884:2002 Milk fat. Preparation of fatty acid methyl esters.

21. ISO 15885:2002 Milk fat. Determination of fatty acid composition by gasliquid chromatography. 